\title{
High Pressure Bioscience - Basic Concepts, Applications and Frontiers
}

赤坂一之・松木 均 $[$ 編 $]$ 。
Springer， 2015 年，730ベ，\$259.00. (e-Book は \$199.00，各章每の購入も可)

高圧力バイオサイエンスに関する成書が，日本人 研究者の編集によりSpringer 社から刊行された. 今 から約 100 年前, Bridgman が 7,000 気圧以上まで 加圧すると卵白が固まることを報告し，その半世紀 後, 鈴木や Hawley らがその熱力学解析への端緒を つけた. 1980 年代には林が食品への圧力利用に先 鞭をつけ，そして今日では，赤坂らが高圧 NMRに より蛋白質への圧力効果を原子レベルの分解能で解 き明かし，高圧力バイオサイエンスはまさに新しい 時代を迎えている. 本書は，(1) 圧力がもたらした 蛋白質・脂質等生体分子の新しい動的な姿とその研 究法を示すと共に，(2) 圧力による細胞生理の研 究, 圧力の食品加工への利用法, など, 高圧力バイ オサイエンスの基礎概念からその応用および最先端 技術までを包括的に解説する． 700 ページを超える 本書は単なる総説の寄せ集めでなく, 圧力と生体分 子の関わりを基礎から学ぶために書き下ろされた解 説書であり, また, 食品から生体生理に至る幅広い 範囲において, 圧力の関わりを例示し, 広い視野か ら学ぶのに適した専門書である.

全 33 章にわたる本書は, 主題に沿って7つの Partに分けられ，圧力と生体分子との基本的で歴史 的な関わりを, 基礎理論から応用までを網羅してい る. Part I は蛋白質がなぜ圧力で変性するのか ? と いう 100 年来の歴史的疑問に最先端の研究者（理論 と実験）が真っ向から応える.ここ 10 年の進展に 基づいた，この分野最高の成書である. Part II, Part III は蛋白質の動態研究に焦点を当て, 歴史的な圧縮 率研究から近年の高圧 NMR による励起構造と水の 役割が述べられる. Part IVではフォールディングと 凝集機構が取り挙げられる. Part V，Part VIでは生体 膜動態と細胞の圧力応答・適応が詳細に解説され る. Part VII では最近活性化が著しい食品加工への圧 力利用の先端的取り組みが披露される. Part VIII で
は, バクテリアから人に至るまで, 我々は日常気づ かないが, 生命活動と圧力の切っても切れない関係 が明かされる. Part IXは, 近年進展した構造と熱力 学を結びつける実験手法である, 高圧下における X 線散乱, X線結晶学, 蛍光と NMR の技術が説明さ れる.

本書は, 生体分子が関係する全分野の研究者に とって有効で新鮮な力を与えてくれる. 圧力利用を めざす研究者や大学院生にとっては, これまで得ら れなかった基本情報を提供する教科書として, 普遍 的な価值を持つ. 対象とする分野の広さから, 応用 分野についても参考となり, 将来に亘って価值ある ものとなるであろう.

（京都府立大学 織田昌幸）

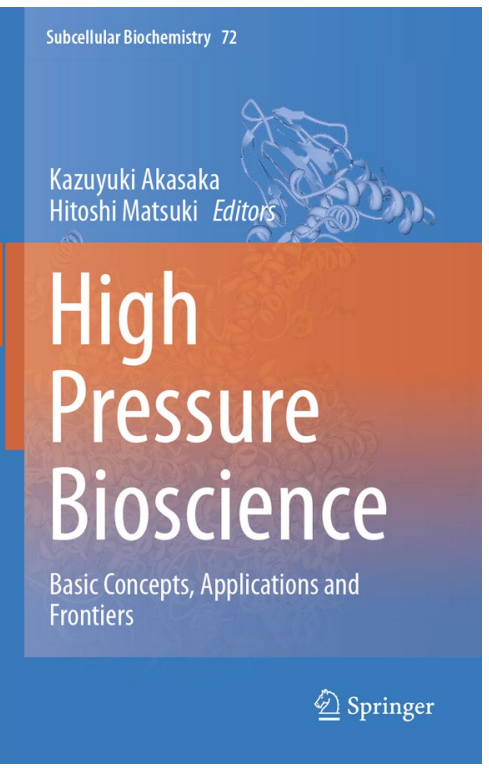

